О. Є. Ратбиль // Неврологічний журнал. - 2007. - № 2. C. $65-68$.

\section{References}

1. Beseda, V. V., Romanchuk, O. P. (2012). Do pytannia otsinky fizychnoi pidhotovlennosti ditei doshkilnoho viku. Issue 19 [By the assessment of physical readiness of preschool children. Issue 19]. Kamjanec-Podilskyj: Medobory, 237-243.

2. Robyenesku, N. (1972). Nejromotorne perevihovannja [Neyromotor learning]. Buharest: YETM, 268.

3. Bukhovets, B. O. (2014). Bobat terapiya v korektsiipsiho-motornogo rozvitku ditey z organichnimi urazhennyami [Bobath therapy in the correction of psychomotor development of children with organic lesions]. Nauka i osvita, 8, 30-35.

4. Tarasun, V. V. (2012). Psihologo-pedagogichna dopomoga ditjam pereddoshkilnogo viku $\mathrm{Z}$ osoblivostjami vrozvitku: naprjami realizaciï [Psycho-pedagogical assistance to preschool children with featuresin development: directions of realization]. Kiev: Vidavnictvo Nacionalnogo pedagogichnogo universitetu imeni M. P. Dragomanova, 412.

5. Gluschenko, M. N., Romanchuk, A. P. (2013). Effect of the complex breathing exercises with massage gymnastics on physical readiness of children with CNS. Journal Of Health Sciences, 3 (4), 349-356.

6. Forssberg, H. (1999). Impaired griplift synergy in children with unilateral brain lesions. Brain, 122 (6), 11571168. doi: 10.1093/brain/122.6.1157
7. Badalyan, L. O., Zhurba, L. T., Timonina, O. V. (1988). Dityachi tserebralni paralschi [Cerebral palsy]. Kyiv: Zdorove, 328.

8. Romanchuk, A. P., Beseda, V. V. (2009). Metodichni aspekti provedennya ta organizaciï masazhnoï gimnastiki $u$ rann'omu vici [Methodological aspects of massage and gymnastics organization at an early age]. Medichna reabilitacija, kurortologija, fizioterapija, 4, 37-40.

9. Celnik, P., Hummel, F., Harris-Love, M., Wolk, R., Cohen, L. G. (2007). Somatosensory Stimulation Enhances the Effects of Training Functional Hand Tasks in Patients With Chronic Stroke. Archives of Physical Medicine and Rehabilitation, 88 (11), 1369-1376. doi: 10.1016/j.apmr.2007.08.001

10. Bobat, K. (1966). Motornidefekti u patsientiv z tserebralnim paralichem. [Motor defects in patients with cerebral palsy]. Saffolk: Svobodna presa, 56.

11. Rejn, S., Medouz, L., Linch-Jellerington, M. (Eds.) (2013). Bobat Concept. Teoriya ta klinichna praktika V nevrologii i reabilitacii [Theory and clinical racticein neurological rehabilitation]. Nizhniy Novgorod: Kirilitsya, 320.

12. Finni, N. R. (2009). Ditina z cerebralnim paralichem. Dopomoga. Dogljad. Rozvitok [Child with Cerebral Palsy. Help. Care. Development. Book for Parents]. Moscow: Terevinf, 330.

13. Damulin, V. V., Trushyna, Je. N., Javors'ka, S. A., Ratbyl', O. Je. (2007). Psihogenni ruhovi porushennya [Psychogenic movemen disorders]. Nevrologschniy zhurnal, 2, 65-68.

Рекомендовано до публікаиії д-р пед. наук, професор Долинський Б. Т. Дата надходження рукопису 26.01.2016

Буховець Божена Олегівна, аспірант, кафедра теорії та методики фізичного виховання лікувальної фізкультури та спортивної медицини, ДЗ «Південноукраїнський національний педагогічний університет ім. К. Д. Ушинського», вул. Старопортофранківська, 26, м. Одеса, Україна, 65020

E-mail: bowena045@gmail.com

\author{
UDC 378.14:65+378.4.046.4 \\ DOI: $10.15587 / 2313-8416.2016 .60621$
}

\title{
REAL PROBLEM-BASED LEARNING: SPECIFIC FEATURES OF THE TRAINING METHOD FOR CREATION OF MODERN INDUSTRIAL CONTROL SYSTEMS (BASED ON THE EXPERIENCE OF THE EUROPEAN UNIVERSITIES PARTICIPATING IN TEMPUS MEDIS)
}

\author{
(C) O. Galchonkov, A. Nevrev, N. Loziienko
}

Основна мета статті - висвітлити ключові підходи реального проблемно-орієнтованого навчання (РПОН) побудови сучасних промислових систем управління, щчо використовується провідними європейськими університетами. РПОН, направлено на отримання студентами навичок роботи з реальними замовниками систем управління і провідними експертами при проектуванні засобів автоматизачіі

Ключові слова: проблемно-орієнтовано навчання, просунуте проблемно-орієнтовано навчання, реальне проблемно-орієнтовано навчання, ітерація, Agile методологія

The main aim of the article is to cover the key approaches for improving the problem-based learning $(P B L)$ in the context of students' training for the design of modern industrial control systems. The study revealed the transformation of PBL into two complementary areas of training: Advanced Problem-Based Learning (APBL) and Real Problem-Based Learning $(R P B L)$. The feature of APBL is the simultaneous study of several interconnected subjects on the base of projects implementation which requires the use of all of these subjects. RPBL complements APBL by training students the missing knowledge and skills through performing real projects for industrial enterprises. It is depicted that in-between transition from PBL to APBL and RPBL the role of teacher is changing. If in PBL the teacher supervises and controls the progress of the project implementation, then in APBL teacher plays the guide role from the formulation of the problem to its solution. In RPBL teacher partially becomes a member of the team carrying out the projects. Specific features of RPBL realization methodology are considered in terms of TEMPUS MEDIS project realization

Keywords: problem-based learning, advanced problem-based learning, real problem-based learning, iteration, Agile methodology 


\section{Introduction}

The level of industry automation has an inextricable connection with the specialists' skill level necessary for the design of new control systems. Increase of the automation level has led to wide implementation of PBL at the universities of Europe starting from 1990s as the means directed towards improvement of professional skills of the graduates. However, now it is not enough, and PBL has gained further momentum in the form of Advanced Problem-Based Learning (APBL) [1] and Real Problem-Based Learning (RPBL).

The methodology of PBL assumes the usage of students' solution of various cases (problems) as the main mechanism of their learning [2, 3]. The key point of the method herein is maximization of students' independence during the case solving. They should themselves ask the questions required for the problem solving and find the answers to them by searching necessary information and having joint discussions. In this case, the role of professors essentially changes. They stop being the main source of knowledge, and become tutors, who control the case solving process and channel it as necessary. The cases are solved in small groups. There are either no lectures or very few of them and they concern only what is necessary for the solving of specific cases. Some subjects are still taught to the students, but they are now divided not into a complete set of theoretical topics, but into a range of problem-based cases involving only the main topics. It leads to the replacement of completeness of theoretical knowledge on a subject with practical experience of solving particular problems connected to it. With that, the problem solving involves the whole range of questions from setting the problem to designing the control systems and supporting them in the production. The training using PBL methodology is directed towards the formation of students' skills for complete problem solving from the problem-setting to practical implementation, which should also allow solving those problems the students had no primary academic training for.

\section{Advanced Problem-Based Learning}

The next step to increase the training level of the specialists designing automated control systems was usage of Advanced Problem-Based Learning, and Real Problem-Based Learning complementing it [1, 4-9]. APBL is directed towards the students' training based on performance of educational cases created beforehand, with their main objective being complex mastering of the modern methods and tools for industrial control systems making by the students. Real Problem-Based Learning assumes real projects performance by the students, for which the most effective options of control systems making are not pre-known. As a result, a control system should be designed with parameters and functionality essentially better than those of its industrial analogs so that to completely satisfy the needs of a specific customer.

The enhancement of learning efficiency in APBL has been reached by joint learning of several interconnected subjects. Educational cases to be solved by the students are not restricted by one subject and can be solved using various equipment and software as well as require the complex usage of all the subjects. The solving of such cases allows the students to take their lead regarding the specific features of various equipment and software faster and more thoroughly, and to develop skills for the most reasonable choosing of technologies for various problems solving.

The introduction of APBL requires a more complex methodological support, as the cases being solved require the complex use of the knowledge obtained within various subjects constituing one package. Teaching of all the subjects from the package should not be isolating, but should certainly include a comparison of specific features of the solutions offered by the subject with those offered by another one, as well as the review of practical conditions under which these solutions are the most appropriate. In addition, special attention should be given to the enhancement of efficiency of the designed control systems in case of complex use of tools reviewed in various subjects.

Structuring the students' learning process in accordance with APBL methodology allows covering a wider range of technologies used in the modern information control systems design. Without that, one can never benefit from all the opportunities available to the developers due to constantly growing nomenclature and increased hardware functionality, as well as increasingly effective software created for them. The constantly expanding range of technologies the students should master also changes the professors' role in APBL as compared to the classic PBL. At the beginning of PBL implementation the number of studied technologies was not as large, and the main focus was on the students' independent work on the cases. The professor acted as a tutor, who monitored the process of the case solving and would point out the necessary changes of the efforts application if required. The students working on the case solution actually worked their way up from the problem's formal statement to a complete solution of the case independently, including the potential implementation issues and support of the designed information control system in the production. However, since the beginning of the mass PBL implementation in the 1990s both hardware and software have dramatically increased their nomenclature, functionality, and complexity. With that, the duration of students' training remained the same. Therefore, a natural need arose to change the role of the professors. In APBL every professor teaching a subject from the package acts as a stalker (guide) helping the students to master at least one effective way to solve the case.

\section{Real Problem-Based Learning}

To increase the students' competence the approach of the real cases solution for the benefit of a particular industial enterprise known as RPBL is used. RPBL methodology differs significantly from APBL methodology, and assumes that the students have already studied the main bulk of knowledge based on educational cases. The main principles here are the following:

1. A real control system is designed for a particular enterprise to be tested and commissioned.

2. The period between the problem statement and the commissioning should be as limited as possible and in no case exceed the scope of the educational process. 
3. The goal is to exceed the technical and economic parameters and the functionality of the known industrial analogs.

4. The acquired solution should be worked through as much as possible for the reproduction and commercial realization.

5. There should be worked out either the options for the system's further modernization after its commissioning or the options for designing next generations of similar systems.

The approach to the project implementation is borrowed from Agile methodology [10] modified for the students' design of real control systems within the educational process.

The designing is carried out as series of short cycles called iterations, which usually last 1-2 weeks each. An iteration involves realization and testing of some devices and software that secure one or more of the designed system's functions. The obtained positive results are documented and subsequently become a template for the production of the final documentation. At the end of each iteration, the group of students working on the project performs revaluation of the main priorities and further steps.

The main distinctive feature of the students' implementation of the project in RPBL from the same implementation at the enterprise lies in its maximum transparency and publicity. Each iteration result is discussed at a seminar with special field professors of the university. The leading specialists of the customer are involved in the tests and result discussions, and may change the requirements for the control system based on the current status of the project and needs of the enterprise. The project current status in terms of critical decisions on the used equipment, software, control algorithms, and functionality is discussed at each iteration with the maximum number of leading industry experts collaborating with the university under RPBL.

The professors in RPBL have two basic functions. First, the professors that taught the package of subjects under APBL methodology serve as experts. Second, these professors act as organizers helping to contact with independent industry experts and the project customers. At the same time, they act as members of the students' group working on the project.

The opinions and wishes of the project customers have high priority in planning the next steps of the design. As for the industry experts, it is desirable that they represent the widest range of the latest technologies and have detailed reasoning as to the benefits, features, development prospects, and implementation experience of the technology. The students' tasks include the choice and implementation of the most rational option.

\section{The main results of RPBL in TEMPUS MEDIS project investigation}

The TEMPUS MEDIS project contains a "block"of subjects studied parallelly and interdependently, which are aimed at training of specialists for the design of modern industrial control systems. With that, the use of the following hardware and software is studied:
- industrial computers together with stock inputoutput signal devices;

- tablets with standard graphical information display software and Bluetooth and Wi-Fi communication software;

- modern microcontrollers for making control systems using the example of the estimator STM32F429IDISCOVERY and IAR environment framework;

- standard fieldbuses for making distributed industrial control systems (RS232, RS485, I2C, CAN, MODBUS, etc.);

- wireless communication channels (Bluetooth and Wi-Fi for communication between tablets, tablets and desktop computers, tablets and microcontrollers, etc.).

Much attention is paid here to the possibility of modeling a control system built on the basis of the above mentioned components, so that it would be possible to check the system's operability and determine the characteristics of the described variant of system making. It saves the designing time and cost by eliminating the work with real hardware in the early design stages.

Similarly to the classical PBL, one of the most important conditions in RPBL is the active cooperation between the students. At that the following objectives are set:

- improving the teamwork skills;

- dynamic distribution of the workload among all the group members;

- each member of the group does their own part, but all students should master the work technologies and the results obtained by each one of them;

- maximizing the effectiveness from collaboration with experts and customers of the project;

- collaborative decision-making on the control system;

- systematic elaboration and presentation of the decisions made and the results obtained.

The project is carried out in a format that complies with the standards adopted by the project customer. The key points of the project implementation are as follows:

- General statement of the problem;

- Distribution of roles in the team and division into sub-tasks;

- Selection and reasoning of the most effective ways to solve the problem;

- Selecting the most effective set of software and hardware to solve the problem;

- Examination of the project;

- Bringing the project to the practical implementation stage;

- Pre-commissioning; operation;

- Acceptance tests for all the possible modes of

- Full documentation of the implemented project;

- Presentation of the project.

According to Agile methodology, these key points are passed not once, but following an expanding upward spiral, with its each turn embodying the more and more perfect and complete solution for the control system. 
A significant advantage of RPBL lies in the creation of positive motivation to learning through forming a sense of confidence in one's own knowledge and skills with, in fact, real professional activity at a particular enterprise and creation of a control system exceeding known industrial systems by a number of parameters.

\section{Conclusions}

The TEMPUS MEDIS project aims at implementation of both RPBL and APBL into the specialists' training process for modern industrial control systems. The main methodology used is APBL. RPBL complements it in order to reduce the gap between the educational projects and the subsequent work in the industry. It should be noted that the task of ehnancing the students' learning efficiency is relevant for many areas of study. Therefore, a combination of RPBL and APBL methodologies can be used not only for teaching the industrial control systems design, but also in many other areas, including research activities.

EU universities have accumulated a considerable experience in the use of RPBL and APBL for the learning efficiency improvement. The TEMPUS MEDIS project has made it possible to combine the experience of five European universities as to the specialists' training in the field of modern industrial control systems and to share this experience with six universities of Kazakhstan, Russia, and Ukraine. The implementation of RPBL anf APBL methodologies into the learning process in these universities under the TEMPUS MEDIS project will allow further implementation of these methodologies into other areas of study.

\section{References}

1. Galchonkov, O. M. Advanced problem-based learning. The experience of the European universities participants to the TEMPUS MEDIS project [Text] / O. M. Galchonkov, N. V. Loziienko // Pr. Odes. politehn. un-tu. - 2015. - Issue 2. P. 195-200. doi: 10.15276/opu.2.46.2015.33

2. Rhem, J. Problem-Based Learning: An Introduction [Text] / J. Rhem // The National Teaching \& Learning Forum. 1998. - Vol. 8, Issue 1. - P. 1-4. - Available at: http://utminers.utep.edu/robertson/pdf/introduction_pbl_article.pdf

3. Iskrenko, E. V. Problemno-orientirovannoe obuchenie: osobennosti metodiki prepodavaniya $\mathrm{v}$ Velikobritanii (na primere St. George University of London, Great Britain) [Text] / E. V. Iskrenko, T. A. Polton // Zh. Nauchnyie vedomosti Belgorodskogo gosudarstvennogo universiteta. Seriya: Istoriya. Politologiya. Ekonomika. Informatika. - 2008. - Vol. 10, Issue 8. - P. 214-218.

4. Hassan, H. Innovative Methodology to Improve the Quality of Electronic Engineering Formation through Teaching Industrial Computer Engineering [Text] / H. Hassan, J.-M. Martinez, C. Dominguez, A. Perles, J. Albaladejo // IEEE Transactions on Education. - 2004. - Vol. 47, Issue 4. P. 446-452. doi: 10.1109/te.2004.825541

5. Hassan, H. Remote laboratory architecture for the validation of industrial control applications [Text] / H. Hassan, C. Dominguez, J.-M. Martinez, A. Perles, J. Albaladejo // IEEE Transactions on Industrial Electronics. - 2007. - Vol. 54, Issue 6. - P. 3094-3102. doi: 10.1109/tie.2007.907015
6. Hassan, H. Integrated Multicourse Project Based Learning in Electronic Engineering [Text] / H. Hassan, C. Domínguez, J. M. Martinez, A. Perles, J. Albaladejo, J. V. Capella // International Journal of Engineering Education. - 2008. - Vol. 24, Issue 3. - P. 581-591.

7. Hernando, M. Ten Years of Cybertech: The Educational Benefits of Bullfighting Robotics [Text] / M. Hernando, R. Galan, I. Navarro, D. Rodriguez-Losada // IEEE Transactions on Education. - 2011. - Vol. 54, Issue 4. - P. 569-575. doi: 10.1109/te.2010.2095014

8. 544490-TEMPUS-1-2013-1-ES-TEMPUS-JPCR. A Methodology for the Formation of Highly Qualified Engineers at Masters Level in the Design and Development of Advanced Industrial Informatics Systems [Text]. - Universitat Politecnica de Valencia, 2013.

9. Savery, J. R. Problem-based learning: An instructional model and its constructivist framework [Text] / J. R. Savery, T. M. Duffy; B. G. Wilson (Ed.). - Constructivist Learning Environments: Case Studies in Instructional Design. New Jersey: Educational Technology Publications, 1996. P. 135-148.

10. Agile_software_development [Electronic resource]. Wikipedia. - 2015. - Available at: https://en.wikipedia.org/ wiki/Agile_software_development

\section{References}

1. Galchonkov, O. M., Loziienko, N. V. (2015). Advanced problem-based learning. The experience of the European universities participants to the TEMPUS MEDIS project. Pr. Odes. politehn. un-tu., 2, 195-200. doi: 10.15276/opu.2. 46.2015.33

2. Rhem, J. (1998). Problem-Based Learning: An Introduction. The National Teaching \& Learning Forum, 8 (1), 1-4. Available at: http://utminers.utep.edu/robertson/pdf/ introduction_pbl_article.pdf

3. Iskrenko, E. V., Polton, T. A. (2008). Problemnoorientirovannoe obuchenie: osobennosti metodiki prepodavaniya v Velikobritanii (na primere St. George University of London, Great Britain). Zh. Nauchnyie vedomosti Belgorodskogo gosudarstvennogo universiteta. Seriya: Istoriya. Politologiya. Ekonomika. Informatika, 10 (8), 214-218.

4. Hassan, H., Martinez, J.-M., Dominguez, C., Perles, A., Albaladejo, J. (2004). Innovative Methodology to Improve the Quality of Electronic Engineering Formation Through Teaching Industrial Computer Engineering. IEEE Transactions on Education, 47 (4), 446-452. doi: 10.1109/te.2004.825541

5. Hassan, H., Dominguez, C., Martinez, J.-M., Perles, A., Albaladejo, J. (2007). Remote Laboratory Architecture for the Validation of Industrial Control Applications. IEEE Transactions on Industrial Electronics, 54 (6), 3094-3102. doi: 10.1109/tie.2007.907015

6. Hassan, H., Domínguez, C., Martinez, J. M., Perles, A., Albaladejo, J., Capella, J. V. (2008). Integrated Multicourse Project Based Learning in Electronic Engineering. International Journal of Engineering Education, 24 (3), 581-591.

7. Hernando, M., Galan, R., Navarro, I., RodriguezLosada, D. (2011). Ten Years of Cybertech: The Educational Benefits of Bullfighting Robotics. IEEE Transactions on Education, 54 (4), 569-575. doi: 10.1109/te.2010.2095014

8. 544490-TEMPUS-1-2013-1-ES-TEMPUS-JPCR. A Methodology for the Formation of Highly Qualified Engineers at Masters Level in the Design and Development of Advanced Industrial Informatics Systems (2013). Universitat Politecnica de Valencia.

9. Savery, J. R., Duffy, T. M.; Wilson, B. G. (Ed.) (1996). Problem-based learning: An instructional model and its 
constructivist framework. Constructivist Learning Environments: Case Studies in Instructional Design. New Jersey: Educational Technology Publications, 135-148.
10. Agile_software_development (2015). Wikipedia. Available at: https://en.wikipedia.org/wiki/Agile_software_development

Рекомендовано до публікаиії д-р пед. наук, професор Корнешук В. В. Дата надходження рукопису 20.01.2016

Galchonkov Oleg, PhD, associate professor, Department of Information Systems, Institute of Computer Systems, Odessa National Polytechnic University, Shevchenko ave., 1, Odessa, Ukraine, 65069

E-mail: o.n.galchenkov@gmail.com

Nevrev Alexander, PhD, associate professor, Department of Information Systems, Institute of Computer Systems, Odessa National Polytechnic University, Shevchenko ave., 1, Odessa, Ukraine, 65069

E-mail: a.i.nevrev@gmail.com

Loziienko Natalia, Leading Specialist, Department of Marketing and Innovation Policy, Odessa National Polytechnic University,Shevchenko ave., 1, Odessa, Ukraine, 65069

E-mail: lebednatalya@gmail.com

УДК 37.015.31:7-053.5]:821.161.2-92
DOI: $10.15587 / 2313-8416.2016 .60901$

\title{
РОЗВИТОК ТВОРЧИХ ЗДІБНОСТЕЙ ДИТИНИ ЗАСОБАМИ ОБРАЗОТВОРЧОГО МИ- СТЕЦТВА (НА ПРИКЛАДІ АНАЛІЗУ ЗМІСТУ РУБРИК ДИТЯЧОЇ ПУБЛІЦИСТИКИ)
}

\author{
(C) О. А. Жукова, В. Ф. Стратілат
}

У статті дитячу публіцистику представлено як засіб, щзо має вагомий вплив на формування і розвиток творчих здібностей вихованців. Із загалу украйнських періодичних видань авторами виділено дитячі журнали, що сприяють творчому розвиткові молодших школярів. Дано аналіз змісту завдань творчих рубрик періодччних дитячих видань, які за допомогою засобів образотворчого мистецтва сприяють формуванню та розвитку в них емоційно-естетичного досвіду, культури почуттів, позитивного ставлення до дійсності, творчої активності

Ключові слова: дитяча публіцистика, образотворче мистецтво, креативне мислення, творча активність, творча самостійність, творчі здібності

In the article was considered the problem of development of child creative abilities by means of fine art. There were single out the forms of its study, the special attention was paid to the independent activity of child in carrying out creative tasks contained in the rubrics of modern children journalism.

With the help of methods of qualitative and quantitative analysis, systematization, typologization, periodization of informative sources from Ukrainian periodical issues there were singled out children journals that favor the creative development of junior schoolchildren.

There was presented an analysis of content of creative task rubrics in periodical children issues: «Barvinok», «Bogdan, «Veselochka», «Djmil», «Givoj rodnichok», «Kolosok», «Luchik», «Parostok», «Piznajko», «Jablunka». There were defined the types of work carried out by children. There was outlined the character of creative tasks.

There was made conclusion that the tasks of creative rubrics of children periodical issues stimulate the manifestation of creative potential of junior schoolchildren and also have a positive influence on the process of formation and development of their specific personal qualities (purposefulness, persistence, quick-wittedness and inventiveness, confidence, reasonableness and validity of activities)

Keywords: children journalism, fine art, creative thinking, creative activity, creative independence, creative abilities

\section{1. Вступ}

Виховання дитини в умовах сучасного соціуму має тісний зв'язок із розвитком у неї потреби у творчості. Підгрунтям творчого ставлення молодших школярів до виконання будь-якої суспільно-корисної справи $є$ наявність сформованих особистісних якостей, серед яких чільне місце займають: допитливість; ініціативність; жвавість й швидкість сприйняття інформації та генерації ідей; увага; багата уява; креативність; здатність до прийняття власних оригінальних рішень. За їх допомогою дитина намагається зрозуміти навколишній світ та пояснити ті чи інші явища, з яки- 